\title{
A FUNDAÇÃO DE SÃO PAULO PELOS JESUÍTAS.
}

\begin{abstract}
"Outra (povoação) está doze léguas pela terra dentro, chamada São Paulo, que edificaram os Padres da Companhia". Pero de Magalhães Gandavo, História da Provincia de Santa Cruz (1576), ed. de São Paulo, 192\%, pág. 76 .

"Muitas destas fontes históricas... são documentos da Companhia de Jesús, que foi a própria fundadora da grande Cidade e o foco inicial da cultura paulista, com o seu famoso Colégio." — S. Leite, VI, XVII.
\end{abstract}

\section{I - LEONARDO NUNES, O PIONEIRO}

Enviado pelo Padre Manuel da Nóbrega, chegou a São Vicente, em princípios de 1550 . De Ilhéus trouxera consigo um grupo de índios carijós, catequisados anteriormente por franciscanos, salteados depois por colonos do Brasil, preadores de escravos, e postos então em liberdade, por ordem de Tomé de Sousa e a pedido de Nóbrega, índios que deveriam restituir a suas terras, apenas se reunissem todos os libertados, para lá os evangelizar (1).

Recebido com alvoroço pelos colonos de São Vicente, a primeira coisa que fêz (2) foi subir ao planalto, onde viviam espathados entre os índios, privados de tôda assistência religiosa, certo número de portuguêses. Induziu-os a juntar-se em tôrno de uma ermida, que fêz então construir e que, em 1553, aqui encontrou Tomé de Sousa, consagrada a Santo André. Dêsse local se adiantou quatro ou cinco léguas, visitando aldeias de índios, aos quais propôs, por meio de intérpretes que o acompanharam, seus planos de catequese. Quiseram os índios que ficasse entre êles.

Retornando a São Vicente, ali com auxílio do capitão-mór Antônio de Oliveira, de Luís de Góis e dos moradores em geral, empreendeu a construção de um vasto templo e de uma boa casa, onde pensava educar os filhos dos índios amigos, como já se estava fazendo na Bahia. Recebeu então na Companhia dois co-

\footnotetext{
(1). - "Carijós" e näo "meninos", é como se deverá ler no texto dessa carta de Nóbrega, conservada em tradução latina (A. S. I. R., Bras. 3 (1) n.0 17, 168-173 v., numeração antiga). A isso obriga o exame da documentação tôda, relativa a essa missão de Leonardo Nunes.

(2). - Na carta de Nunes, em que isso se conta (C. Jes., II, 57-63), excetuada a referência ao Padre Afonso Brás no Espírito Santo e que se explica por êrro de transcrição (bastava por bastará), pede todo o contexto que a data se fixe em 1550, como querem os editôres das Cartas Avulsas.
} 
lonos influentes, grandes "línguas", os mesmos', provàvelmente, que o haviam acompanhado na excursão ao planalto: Pero Correia e Manuel de Chaves. Com o coadjutor Mateus Nogueira, ferreiro, que aceitara na Capitania do Espírito Santo, e o Irmão Diogo Jácome, com quem trabalhara em Ilhéus, formou assim a primeira comunidade jesuítica em São Vicente.

Seu zêlo sacerdotal, sua atividade incansável, foram produzindo desde logo admiráveis frutos de regeneração cristã. A comunidade, igualmente, ia crescendo com a admissão de novos elementos: João de Sousa, André do Campo e outros. Em agôsto de 1550 eram oito. Em junho de 1551 eram catorze. Já então funcionava a escola de catecúmenos. Em maio de 1551, entrava de novo o Abaré-bebê pelo sertão, até Maniçoba, provàvelmente.

Nesta viagem se deu o choque com João Ramalho e a sua geração, dada a situação irregular do patriarca em face da Igreja. Corajoso e humilde, cumpriu Nunes sem tergiversações o seu dever, preparando afinal a conversão do guarda-mór do Campo, que se dará em 1568 .

Dessa excursão, além de, seguramente, bom número de corumins das aldeias do planalto, trouxe também certo cristão como já sucedera da primeira vez -, reduzido ao embrutecimento pela doença e a vida selvagem.

Insistiam os indios que lhes pregasse a fé. Unico sacerdote na casa de São Vicente, já não podia abandoná-la. Para animar, porém, "assim portuguêses como índios", thes anunciava a vinda. de novos jesuítas de Coimbra, que seriam então distribuidos "em tal e tal parte" (3).

Era, ideològicamente, o esbôço do que, três anos mais tarde, fracassada a "emprêsa do Paraguai" (4), se veio a realizar com a fundação de São Paulo.

Com a chegada do Padre Manuel de Paiva em 1552, esteve Leonardo Nunes, conforme projetara desde o ano anterior, para ir ao Paraguai, donde se renovavam os apelos de espanhóis e de índios para a ida até lá do Abaré-guaçú, o grande missionário (5). Se desistiu, foi provàvelmente, com a notícia da próxima vinda a São Vicente do Padre Manuel da Nóbrega.

\section{II - NÓBREGA EM SÃO VICENTE}

Com o mês de fevereiro de 1553 e na flotilha de Tomé de Sousa, aportou a São Vicente o Superior da missão jesuítica no Brasil. Da Bahia se retirara êle profundamente ressabiado com

\footnotetext{
(3). - C. Jes., II, 103.

(4). - S. Leite, II, 239.

(5): - Barcaclué ou Barcacliú (S. Vasconcelos, Crônica, L. I. \$ 131; S. Leite, Novas C. Jes., 140) originam-se de Bareachú, forma que se lê na cópia de Roma (A. S. I. R., Bras. 3 (1), 89). Abaré-guaçú era, pois, como denominavam os carijós a Leonardo Nunes.
} 
a oposição de D. Pedro Fernandes Sardinha, o primeiro Bispo, para cuja vinda contribuira mais que ninguém, promovendo a criação do bispado de Salvador. Traduzem a amargura dessa decepção suas cartas, até muitos anos depois. Lá não voltará, enquanto êste, por sua vez, não se afastar, chamado para a Côrte.

Em São Vicente, atraía-o, com as informações recebidas, a obra de Leonardo Nunes, orgânica, silenciosa e tenaz, o que de mais grandioso haviam realizado até então os jesuítas no Brasil. Vinha, com efeito, encontrar ali uma bela Igreja, como sequer no. Reino a possuiam ainda os padres da Companbia. Vastos edificios, onde mais de oitenta pessoas, entre jesuítas, candidatos à Companhia, alunos indígenas e servidores, desenvolviam suas atividades para o aperfeiçoamento próprio e o bem da Capitania. A. presença da Companhia em São Vicente era abençoada geralmente por todos.

Sua primeira providência, ao desembarcar, é dada a 2 de fevereiro de 1553, erigindo em confraria do Menino Jesús o estabelecimento de São Vicente, como já fizera na Bahia, criando-lhe assim a entidade mantenedora. Já que a "emprêsa do Brasil", porém, com a hostilidade do Bispo, a resistência de boa parte dos colonos, enredados nas culpas da injusta escravização dos indígenas ou na dissolúção dos costumes, já não the oferece as perspectivas que idealizara, vem disposto a procurar, se as circunstâncias. assim o aconselharem, novo e mais favorável campo de apostolado.

Reune, dias depois, em consulta os Padres Leonardo Nunes, Manuel de Paiva, Francisco Pires, êste vindo em sua companhia, e alguns irmãos, entre os quais expressamente Pero Correia. Deliberam ir assentar cem léguas para o interior - nas proximidades de Assunção do Paraguai, como então se acreditava (6) e aí fazer casa, juntando os índios carijós em uma grande cidade, para os fazer viver conforme a razão. Do êxito era fiador Pero Correia, com a experiência que dêles tinha.

E o que a 12 de fevereiro comunica ao Padre Simão Rodrigues, em carta de São Vicente. Nesse mês embarca Nunes, a pedido de Tomé de Sousa, a recolher nos Patos os náufragos da expedição de Sanábria. A 15 de junho estará de volta, "muito doente". Ocupava-se, entretanto, Nóbrega, reivindicando em juízo a inocência dos jesuítas, caluniada pela gente de João Ramatho. Ampliava a finalidade da escola dos Meninos de Jesús, admitindo às aulas os filhos dos colonos, e fazendo que aí se dessem as primeiras aulas de latim, por certo jovem gramático desterrado de Coimbra.

Na carta de 15 de junho a Luís da Câmara, declara que vai enviar à Bahia Leonardo Nunes, a trazer de lá a nova expedição. 
missionária que está para chegar. Com êle irá Pero Correia, a ser ordenado. $\mathbf{E}$ até o regresso dêles pretende ir gastando o tempo com os índios do planalto - que insistem em ser cristianizados e para isso querem ajuntar-se de três aldeias muma -, para então entrar pela terra a dentro, onde se dizia haver "melhor gentilidade" que os tupis da costa do Brasil (7).

Até a partida de Nunes, chegado à Bahia, depois do mês de julho - como se colige da primeira carta de Brás Lourenço em agôsto, e talvez em princípios de setembro, êsse era o plano de Nóbrega. Coisa muito diversa, como se vê, da fundação de São Paulo! A êsse plano opusera-se, todavia, enèrgicamente, o Governador Geral. Poderiam os padres internar-se, missionando, nunca, porém, domiciliar-se no sertão. A não ser na medida em. que se fôsse alargando efetivamente o domínio do Rei de Portugal (8).

Sentiu Nóbrega a contradição e, como não recuava fàcilmente dos seus propósitos, recorreu ao Rei, por meio de Luís Gonçalves da Câmara, para que lhe facultasse a ida ao Paraguai, alegando que Assunção - como, aliás, pensava também Tomé de Sousa - deveria estar incluida na demaricação portuguêsa. Na Quadrimestre de maio a setembro de 1554, escrita por Anchieta, reflete-se ainda - como de resto em cartas posteriores de Nóbrega - essa "atração do Guairá". O projeto de uma fundação no campo de Piratininga nem foi o primeiro projeto, nem foi definitivo (9).

\section{III - ALDEIA DE PIRATININGA}

Piratininga era o nome que davam os índios a um "ribeiro afluente do Tietê", que, extravasando na cheia, deixava a secar ao. sol quantidade de peixes, ao refluir para o leito na vazante. Muito se tem discutido sôbre a sua identificação. A carta de Nóbrega, de 2 de setembro de 1557, que o distingue claramente do Tietê ou "Rio Grande" (10); a petição de Luís da Grã, em 1560, e o respectivo despacho (11) para troca de uma data de terras, das suas matgens onde impedia a expansão da Vila, para junto. ao novo caminho do Cubatão, em direção ao rio "Geribatiba-açú", o Rio Grande dos Pinheiros; a discriminação geográfica dêsses rios por Frei Gaspar da Madre de Deus (12), me levam a preferir a. opinião dos que o identificaram com o Tamanduateí (13).

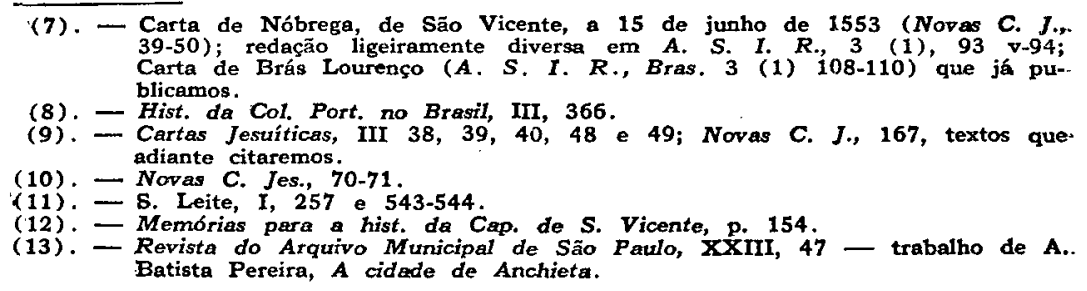


Campos de Piratininga era como se conheceram as terras banhadas por êsse rio, que contornava à sua esquerda ampla e boscosa elevação existente entre êle, o largo vale do Jurupatuba (Rio dos Pinheiros) e que vinha morrer suavemente a meia légua de distância do Anhembí ou Rio Grande, atual Tietê. Nessa região se situava a taba de Tibiriçá, que parece ter-se designado, desde muito, como aldeia de Piratininga. Era uma das várias aldeias distantes quatro ou cinco léguas, em média, de Santo André, que visitara Leonardo Nunes em 1550, 1551 e quiçá ainda no ano seguinte.

Guaianases é como denomina a êsses índios Frei Gaspar da Madre de Deus, nome que já se encontra em Simão de Vasconcelos, sem que se deva necessàriamente aplicar aos mesmos. João Staden, Antônio Rodrigues, Anchieta, os chamam tupiniquins, ou. preferentemente o último, simplesmente tupis, tupis do campo. Contando com a amizade dêsses índios, sôbre os quais se exercia a influência de João Ramalho, com êles aparentado, através de sua união com Bartira, filha - e hoje há quem diga irmã - do Principal Tibiriçá, fundou Martim Afonso, junto ao rio de Piratininga em 1532, uma segunda Vila, além da de São Vicente. A solidão e a ausência de interêsse econômico imediato fizeram que logo se despovoasse, vindo-se todos para o mar - explica Nóbrega - , atraídos pela navegação que os punha em contacto com o Reino.

A sombra, porém, do prestígio do fronteiro do Campo e sua numerosa família, sempre ficaram alguns brancos, os elementos. certamente mais rudes e audazes. A êstes persuadiu Leonardo Nunes. em 1550, que se reunissem em tôrno da ermida de Santo André. Aí os encontrou, já não todos, que de novo se haviam dispersado alguns, o Governador Geral. Obrigou-os a juntar-se, fortalecer a povoação para a defesa. Deu-lhe a categoria de Vila, nomeando-lhe para alcaide e juntamente guarda-mór do Campo, a quem, mais que nenhum outro, para isso fazia jús com o prestígio adquirido e as qualidades reveladas, João Ramalho.

Discute-se a respeito da localização primitiva das tabas piratininganas. A margem do Jeribatiba, mais próxima de Santo André da Borda do Campo e da Serra de Paranapiacaba, estava o velho Caiubí. No Guaré, junto à confluência do Tamanduateí: com o Tietê, a de Tibiriçá. Ou nos Campos Elíseos, querem outros. Ou no Emboaçaba, junto à confluência do Jeribatiba com o mesmo Tietê. Bem poderia ter ocupado sucessivamente todos êstes sítios. Outras aldeias se espalhariam às margens do Tietê, do. Pinheiros e seus diversos afluentes. Sôbre êsse ponto, sôbre o qual tantos e tão acatados pesquisadores da história de São Paulo, Teodoro Sampaio entre os primeiros, têm emitido suas opiniões, dificilmente, dada a escassez de documentos, poderemos passar das conjeturas, mais ou menos bem fundadas. 


\section{IV - PRIMEIRA VISITA DE NOBREGA A PIRATININGA}

A 29 de agôsto de 1553 vinha ter Manuel da Nóbrega a uma aldeia nova, que se chamou de Piratininga e que haviam formado representantes de três dessas tabas indígenas. Reunião operada. anteriormente ao fato histórico da subida de Nóbrega ao planalto. Devida ao desêjo veemente que de há muito nutriam os mesmos: indios de receberem a fé. Não seria justo calar o longo e frutuoso apostolado de Leonardo Nunes, a quem se deve tão auspicioso resultado, para atribuir à ação pessoal de Nóbrega tudo quanto se fêzz para a fundação de São Paulo.

Não se teriam congregado êsses índios na nova aldeia, evidentemente, sem terem a certeza de ver atendido finalmente, pelo maioral dos jesuítas, o seu antigo desêjo de ter consigo os missionários que thes viessem pregar o Evangelho. Com Nóbrega poferiam ter tratado em São Vicente, onde mantinham os próprios filhos, que aí visitavam de quando em quando. Que tenha. havido prévio entendimento entre os tupis do campo e os " $\mathrm{Pa}$ dres", infere-se de vários textos documentais. Nessel lugar "ajuntamos", diz Nóbrega (e não "ajuntei"), os índios que se querem converter. "Por amor de nós" - diz Nóbrega - se veio para a nova aldeia o velho Caiubí. - E Anchieta, sôbre o mesmo Caiubí, afirma que veio por assim the terem dito "os Padres". Texto, no entanto, explícito do mesmo Anchieta, é o que diz: "No ano de 1554, mudou o padre Manuel da Nóbrega os filhos dos: índios ao campo, a uma povoação nova, que os índios faziam por ordem do mesmo Pađre". Modo de falar! Ordem é que não podia ser! Nenhuma jurisdição possuia Nóbrega sôbre êles... Juntaram-se porque muito bem o quiseram. No mesmo documento, acentua Anchieta a inteira liberdade com que, na Capitania de São Vicente, abraçaram os índios a fé (14).

Que a êsse movimento migratório, aliás corriqueiro entre êles, tenha estado presente algum jesuíta, Pero Correia, por exemplo, é possível. Não é certo. Nem sequer provável: narrando sua excursão e o contacto que teve com êsses índios, não menciona Correia essa concentração ou que a tivesse acompanhado ou sequer aconselhado. Prova de que, para os jesuítas de então o acontecimento não tinha, absolutamente, a significação, e a importância que agora the pretendem emprestar (15).

Quanto à atuação pessoal de Nóbrega para isso, temos a afir-. mação expressa de Polanco, secretário de Santo Inácio de Loiola, que assim resumiu contemporàneamente, em Roma, as cartas de Nóbrega e de outros lá recebidas, as mesmas que hoje se apresentam com interpretações tendentes a exaltar essa atuação:

(14). - Cartas Jes., III, 317.

(15). - Carta de Pero Correia, de São Vicente, a 18 de julho de 1554, em Novas: c. J., $170-176$. 
"Num certo campo, doze léguas distante de São Vicente, três aldeias de Brasis haviam determinado reunir-se e fixar sua moradia para poderem ser, todos juntos, catequisados pelos Nossos a mostravam grande vontade de ouvir a palavra de Deus e aprender as coisas da fé". "Depois que os brasis das sobreditas aldeias se reuniram em um mesmo lugar, antes que o Padre Nóbrega deixasse a vila de São Vicente, a êles se dirigiu no mesmo dia da degolação de São João Batista, chegando a êsse lugar, onde habitavam separadamente os que se convertiam à fé de Cristo" (16).

No dia 29 de agôsto de 1553 , ao chegar à aldeia, aí fêz solenemente, Nóbrega, 50 catecúmenos. Iniciava assim, oficialmente, - centro de catequese. Episódio a inserir-se entre os atos precursores da fundação de São Paulo (17). Que nesse dia alimentasse Nóbrega a intenção de fundar aí o primeiro Colégio dos jesuritas no Brasil, ou que para aí pensasse, desde então, transferir a escola de catecúmenos de São Vicente, é o de que não existe prova. A idéia que norteava os passos do superior dos jesuítas, nessa expedição até Maniçoba, era e continuará a ser ainda muito para diante da fundação de São Paulo, a missão dos carijós.

Quanto ao que pretendeu exprimir, ao dizer: "fiz solenemente uns 50 catecúmenos", pode-se discutir. Terá a solenidade consistido nas cerimônias do ritual antigo, que ainda a êsse tempo andava impresso, por exemplo, no missal de Bérgamo? Teriam sido apenas exterioridades outras, mais ou menos aparatosas, sem cunho pròpriamente litúrgico? Missa é que nunca foi cerimônia de recepção de catecúmenos. Isto é certo. Se aí tivesse, aliás; celebra. do Nóbrega, não se explica como Anchieta, que cinco meses depois tratou com êsses mesmos índios e teve como discípulos aos companheiros de Nóbrega nessa excursão, pudesse repetidamente afirmar que a missa de 25 de janeiro de 1554, com que se inaugurou o Colégio de São Paulo, fôsse a primeira que se celebrou. em Piratininga.

\section{V. - A CASA DOS JESUITAS EM PIRATININGA}

"Os índios, por si mesmos, edificaram para nosso uso esta casa" - escreve Anchieta, na Quadrimestre de maio a setembro de 1554. E acrescenta: "mandamos agora fazer outra algum tanto maior, cujos construtores (tradução melhor que "arquitetos") seremos nós mesmos, com o suor do nosso rosto e o auxílio dos índios" (18). Quando Nóbrega diz: "por contemplação (dos moços indígenas) principalmente, fiz aquela casa" (19), é claro que só tem em vista uma intervenção de ordem moral. $\mathbf{E}$ o próprio têrmo "casa" se há de tomar aqui, não no sentido material, a palhoça, mas na acepção jurídica, a instituição.

(16). - J. Polanco, Chronicon S. J., III, 472.

(17): - S. Leite, História, vII, 367 .

118). - C. Jes., III, 43.

(19). - Novas C. Jes., 105. 
A choupana de 14 passos de comprimento por 10 de largo, de paredes de pau-a-pique, coberta de sapé e que, para cerrar a entrada não tinha mais que uma esteira de canas, conforme a descreve Anchieta, quando a terá encomendado Nóbrega a Tibiriçá e seus índios? Em fins de agôsto? Na sua volta de Maniçoba, um ou dois meses depois, para aguardar em São Vicente o refôrço vindo de Portugal? E' o de que não existe documento. Para sua construção, aliás, bastava uma ou duas semanas.

Pela carta de Luís da Grã, de $10^{\circ}$ de novembro de 1556 (20), sabemos que Nóbrega escolheu pessoalmente o sítio em que os índios a levantaram. No alto de uma escarpa da colina de Inhapuambuçú, entre a habitação de Tibiriçá, localizada no atual largo de São Bento, e a taba de Caiubí, na altura da Tabatinguera, distância que se percorria em menos de meia hora, elegeu Nóbrega e apontou ao chefe indígena o sítio escolhido, "o melhor lugar que se poderia escolher", o atual Pátio do Colégio.

A que se destinava a humilde choça? Para habitação dos missionários e mestre-escola dos corumins, - cuja transferência para junto da casa de seus pais, sendo difícil sua manutenção em São Vicente, foi, segundo confessa, a causa determinante da sua resolução? E' o que parece ajustar-se melhor às suas expressões, ao falar dessa fundação, inclusive quando se refere à debandada dos selvícolas, em 1556. Para Nóbrega, isso se afigurava o fim da sua iniciativa: "tudo se perdeu!" o "Colégio dos jesuítas", êsse a que se deve a permanência da fundação, continuava para êle em segundo plano.

Não se poderia, com efeito, em 1553, pensar num "Colégio" como aquêle que se fundou em Piratininga a 25 de janeiro de 1554, sem que antecipadamente se pudesse contar com um professor para regê-lo... E dêle, entretanto, dependeu, como veremos, o futuro de São Paulo. Falamos da instituição jurídica e da entidade moral, mais que da materialidade da construção, que foi tudo quanto podia haver de mais precário e desprezível. Dar importância ao aspecto material da fundação, numa subserviência pueril à cronologia, para minimizar ou eliminar de todo o papel relevante de Anchieta na fundação de São Paulo, equivaleria ao gesto de quem, perante êsse nome de Colégio..., Pátio do Colégio!..., corresse quatrocentos anos para trás, a pregar, em tempo, sôbre a esteira de canas da choça construida, não se sabe exatamente quando, por Tibiriçá em Piratininga, uma tabuleta indicadora: "Colégio de São Paulo, fundado por Manuel da Nóbrega a 29 de agôsto de 1553"; para depois disso exclamar, triunfante: estais vendo? quando Anchieta chegou, o Colégio já existia!

(20): - Carta inédita de Luís da Grā (A. S. I. R., Bras. 3 (1), trecho citado por S. Leite $(I, 279)$, da p. 124 v. 


\section{VI. - UM COLEGIO DA COMPANHIA}

Entre os avisos que deu a Nóbrega, em Portugal, o Padre Simão de Azevedo, ao enviá-lo para o Brasil - recorda o primeiro - estava êste: "que se nestas partes houvesse disposição para haver Colégios da nossa Companhia, ou recolhimento para filhos dos gentios, que eu pedisse terras ao Governador e escoThesse sítios e de tudo the avisasse" (21). "Colégio da Companhia", como se está vendo, designava já então alguma coisa perfeitamente distinta de quaisquer outros estabelecimentos destinados à evangelização de crianças indígenas. A escola fundada na Bahia, em 1550, por Nóbrega, a escola, ou "colégio de catecúmenos", fundado nesse mesmo ano em São Vicente, por Leonardo Nunes, não foram "Colégios da Companhia", se quisermos falar com exatidão.

A instrução da mocidade, que entre as atividades apostólicas dos jesuítas para a reforma cristã da sociedade, se tornou, aos poucos, nas mãos da Companhia uma poderosa alavanca, não estava, originàriamente, entre os meios visados pelo fundador, que não pretendeu, a princípio, senão seminários para a sua Ordem. Tiveram, pois, os Colégios da Companhia sua origem na necessidade da formação intelectual dos seus jovens recrutas. Entre as casas da Companhia, sòmente êsses colégios (aos quais se assimilavam as casas de provação) possuiam bens e podiam viver de rendimentos.

Para se chegar ao tipo de colégio, qual existe hoje, para estudantes não jesuítas, deveremos distinguir várias etapas. Primeira, foi a criação de colégios, junto às Universidades existentes, para que neles estudassem os "escolásticos" da Companhia. Não tardou que, como segunda etapa, se instituissem, com professôres jesuitas, colégios próprios para seus estudantes. Numa terceira fase, ao lado dos seus "escolásticos", foram admitidos outros estudantes de fora.

Foi exatamente essa modalidade que se instalou a princípio no Brasil e se manteve depois, definitivamente, nos dois principais colégios da Companhia no Brasil, na Bahia e no Rio de Janeiro. Este último foi o que teve sua fundação no dia $25 \mathrm{de}$ janeiro de 1554, na aldeia de Piratininga, e descendo daí, anos mais tarde, para São Vicente, se transferiu finalmente para o Rio, na fundação dessa cidade.

O ensino primário nunca fêz parte do programa pedagógico, esboçado, entre 1539 e 1556, por Inácio de Loiola, no Instituto da Companhia de Jesús, através de sucessivos documentos oficiais. Se não se excluia de todo, só se admitia a título de caridade, onde as circunstâncias o pedissem, como no Brasil, onde se ministrou, sempre precária mas eficientemente, por tôda a par-

(21). - Novas C. Jes., 103. 
te, como concessão às peculiaridades do meio e um recurso do evangelização das crianças indígenas, principalmente.

Quando em 1554, criou, por ato de sua privativa jurisdição, em Piratininga, o curso de humanidades para os irmãos da Companhia e outros de fora, candidatos à mesma, e logo mais outros estudantes não destinados ao sacerdócio, e juntamente ali estabeleceu a escola primária dos catecúmenos, não sabia Nóbrega determinar-se sôbre qual fôsse, em face do Instituto da Companhia, a natureza jurídica dessa fundação (22). Sôbre isso escreveu para a Europa, pedindo esclarecimento. Com a chegada das "Constituições", em 1556, compreendeu finalmente - e explìcitamente o reconhece - que a casa de São Paulo não era uma casa de meninos, mas um "Colégio da Companhia" (23). Desde então passou essa casa a ser jurìdicamente o que até aí sempre fôra de fato.

\section{VII. - A CHEGADA DO MESTRE}

A 24 de dezembro de 1553, chegava a São Vicente a leva de religiosos da Companhia, trazida do Norte por Leonardo Nunes. Eram êles Afonso Brás, substituído então, em Vitória, por Brás Lourenço; Vicente Rodrigues, recém-ordenado na Bahia; Gregório Serrão e José de Anchieta, recém-chegados de Portugal; e outro irmão, cujo nome se omite e poderia ser Diogo Jácome, sócio habitual de Leonardo Nunes, e que o teria acompanhado, em lugar de Pero Correia.

Do numeroso grupo de jesuítas que se achou reunido então em São Vicente - se excluirmos Nóbrega, talvez Leonardo $\mathbf{N u}$ nes, Gregório Serrão, que conhecia rudimentos de latim, como, aliás, os deviam conhecer os já sacerdotes -, sòmente.Anahieta possuia de fato formação humanistica. Fôra aluno, desde 1548, provàvelmente, do Colégio das Artes, organizado cuidadosamente, então, por D. João III, em Coimbra. Aí completara êle, com. o mais brilhante êxito, o seu curso de humanidades, para as quais - escreverá o Visitador Inácio de Azevedo, em 1566, informando São Francisco da Borja - tinha qualidades notáveis (24). Naquele mesmo Colégio, já depois de entrado na Companhia de Jesús, a 1.0 de maio de 1551, prosseguira os estudos, completando o curso de lógica e tendo que interromper, por doença, o estudo de filosofia.

Insistem os primeiros biógrafos de Anchieta, Quirício Caxa e Pero Rodrigues, baseados no testemunho de alguns dos mais antigos religiosos da Companhia no Brasil, contemporâneos dêsses fatos, em salientar a estima que desde logo dedicou Nóbrega a

(22). - Novas C. J., 39.

(23): - C. Jes., I, is3.

(24). - Mon. Borgia, IV, 344. 
êste seu novo súdito, cujas grandes qualidades humanas de inteligência e caráter eram superadas ainda pelos dons de graça que espiritualmente o adornavam. Sem documento em contrário, tais afirmações continuarão a merecer-nos plena aceitação. Não foram os anos, mas as riquezas de sua personalidade que the deram, naquelas circunstâncias, o papel de destaque que desde então desemperihou.

"Por falta de mestres" - diz expressamente Quirício Caxa - não tinham os jesuítas de São Vicente até então "nenhum gênero de estudo". Além dos estudantes já recebidos na Compánhia no mesmo caso se achavam outros jovens, candidatos à Companhia, inclusive os órfãos de Lisboa, alguns vindos para São Vicente em 1553, na viagem de Manuel da Nóbrega. Ao tempo da ausência de Leonardo Nunes, desdobrara-se Nóbrega em São Vicente, para suprir ao excepcional obreiro, assegurando o sustento da numerosa comunidade, em que vivia "a maior parte dos Nossos que então havia no Brasil". E também para os trazer ocupados. "Chegado, pois, o irmão José a São Vicente, logo o Padre Nóbrega ordenou lesse gramática aos Nossos e a muitos moços de fora, filhos de portuguêses" (25).

Reuniu então o superior nova consulta, na qual devem ter tomado parte Leonardo Nunes, Manuel de Paiva, Francisco Pires, Afonso Brás e Vicente Rodrigues, sacerdotes presentes na Capitania. E quiçá também alguns irmãos: Pero Correia, que já participara da primeira consulta, havida em fevereiro de 1553 , e, provàvelmente, o novo Mestre, cuja vinda possibilitara a fundação do Colégio.

As informações trazidas da Bahia por Leonardo Nunes, de que D. Duarte da Costa mantinha a proibição de Tomé de Sousa para o plano de internação no continente, ou seja, a "emprêsa do Paraguai"; a experiência de Nóbrega na sua excursão e residência em Maniçoba; a boa disposição dos moradores da "nova aldeia" de Piratininga - lugar central para acudir aos portuguêses e índios do planalto; o clima, aqui bem mais favorável para os estudos; a facilidade para a manutenção dos pupilos indígenas, em casa dos pró prios pais, - tudo isso foi então debatido em São Vicente (26). Pondo então, provisòriamente, de lado o projeto primitivo, decidiu Nóbrega fundar em Piratininga o novo Colégio, transferindo também para cá parte, ao menos, da escola de catecúmenos de São Vicente.

\section{VIII. - OS FUNDADORES DO COLEGIO}

"Aqui se começou o estudo da gramática e a conversão do Brasil", é como se exprime Anchieta, rememorando, na sua Breve in-

(25). - Breve relação, Lisboa, 1934, 12.

(26): - A realização desta nova consuita consta de $\mathbf{s}$. de Vasconcelos (Crônica, $L$. 1, §§ 148-149) e da História Inédita de Antônio de Matos sôbre a fundação do Colégio do Rio de Janeiro - Fondo Gesuítico del Gerú, Collegia, 201). 
formação do Brasil para o Padre Petro Maffeo, as origens de São Paulo de Piratininga (27). E mais abaixo repisa: "A casa de São Paulo de Piratininga, como foi principio da conversão, assim também o foi dos Colégios do Brasil" (28). Colégio e missão! Conjuntamente com o Colégio da Companhia, a escola dos pequenos catecúmenos indígenas - instrumento dos mais eficazes para a evangelização dos selvícolas do campo, outra das finalidades dessa fundação.

Mas o nome de São Paulo, que hoje individua a maior e mais próspera cidade do Brasil, foi dado a 25 de janeiro de 1554, à casa inaugurada em Piratininga pelos fundadores efetivos, por nesse dia, que foi o da chegada, terem celebrado aqui a missa da conversão de São Paulo. Celebrou-a Manuel de Paiva, superior dos doze ou treze jesuítas, para cá de São Vicente enviados pelo Padre Manuel da Nóbrega, vice-provincial e logo mais provincial do Brasil. E essa casa era o Colégio, de que Anchieta foi o professor por então único, e o sustentáculo, durante dez anos seguidos.

Após a festa da Epifania, subiram ao planalto. Com o superior, e além de Mateus Nogueira, que Anchieta coloca entre os que habitaram desde o princípio a nova casa, podemos enumerar ainda os seguintes, dentre os que aponta Simão de Vasconcelos como discípulos de Anchieta: Afonso Brás, Vicente Rodrigues, Diogo Jácome, Pero Correia, Manuel de Chaves, Leonardo do Vale, Gaspar Lourenço. Com maior ou menor presunção, podem ainda ser indicados: Gonçalo de Oliveira, Fabiano de Lucena e Antônio Rodrigues, cuja presença, dêstes dois últimos, é certa no segundo semestre; Simeão Gonçalves, e o mameluco Cipriano, candidatos ainda; e o Irmão João de Sousa, cozinheiro. De Gregório Serrão, conta Anchieta que, detido em São Vicente a princípio, por doença, veio tempos depois, sendo seu discípulo em Piratininga.

Dêsse grupo de treze ou catorze jesuitas, que no dia 25 de janeiro fundaram efetivamente o Colégio de São Paulo, como nova comunidade religiosa e "célula-mater" que foi da cidade de São Paulo, é de justiça destacar, como, aliás, sempre até há pouco se fêz, o nome do Irmão José de Anchieta. Não era êle o superior local, tampouco o responsável por essa fundação. Mas se o "Colégio" se fundou nesse dia e, com êle, a cidade que the herdou o nome, se êsse Colégio sobreviveu em Piratininga o suficiente para que, com a acessão das primeiras famílias portuguêsas, sobrevivesse a povoação e se consolidasse com a transferência de Santo André, em 1560 , isto se deve - eis o fato que não poderá ser suprimido - à presença atuante e benéfica de Anchieta em Piratininga.

De São Paulo seguiam para a Bahia os discípulos jesuítas do Irmão José, e lá eram ordenados sacerdotes, voltando alguns dêles 
para o sul, já revestidos dessa dignidade. Anchieta, cujo preparo intelectual e moral para o sacerdócio daria expressão cabal à frase do Evangelho - "non est discipulus super magistrum", esperou doze anos, na serenidade imperturbável de sua alma humílima, que os superiores se lembrassem dêle. Dêle se lembrou, em tempo, nada menos que o Geral da Companhia de Jesús.

Antes de deixar o cargo de provincial, o que se deu em 1560 , nomeado seu substituto Luís da Grã desde 1559, escrevera Nóbrega, da Bahia, pedindo reforço de gente para o Brasil. De Trento, onde tomava parte no Concílio, escreve, em 1561, o Geral Diogo Lainez, ao Padre Nadal, que diretamente se ocupava do caso: "A grande necessidade de gente que diz (Nóbrega) há no Brasil, se crê. E assim, dos que se enviarem de Itália, como dos de lá (Portugal), verá $\mathbf{V}$. R. a parte que lhes podem fazer. $\mathbf{E}$ entre êles será bem vá algum mestre, pois o Irmão José parece ser só em São $V$ icente e que, em outras coisas de conversão, se poderia empregar mais ùtilmente" (29).

\section{IX. - VICISSITUDES DO COLEGIO DE SÃO PAULO}

Até a fundação do Colégio de São Paulo, e depois disso, o que empolgava o ânimo de Manuel da Nóbrega era a missão dos carijós do Paraguai. Entre as razões da mudança para Piratininga, aponta Anchieta expressivamente a seguinte: "maximé, finalmente, porque se patenteava por esta parte entrada a inúmeras nações, sujeitas ao jugo da razão" (30). "Sujeitas ao jugo da razão - comenta Capistrano de Abreu - consideravam os jesuítas certas tribos que corria terem rei" (31). Eram os carijós e outros gentios na direção do Perú, de que dera notícia o Irmão Antônio Rodrigues. "Estes estão sob a jurisdição dos castelhanos" - acrescenta Anchieta (32).

Na mesma Quadrimestre de maio a setembro de 1554, mencionando a morte de certos índios carijós, conta que Nóbrega ordenara "fôssem por nós levados para sua pátria, para que, com auxílio e favor dêles, pudessem os restantes converter-se à fé de Cristo". "Se algum tempo nos chegarmos àquela nação e a muitas outras suas vizinhas, o maior fruto, esperamos, se colherá delas" (33). Secretário de Nóbrega para essas informações latinas, reproduzia Anchieta fielmente o pensamento do superior. "Esperamos agora - escreve por fim - a cheggada do Padre Luís da Grã, para que se delibere com seu consetho o que se deva finalmente

(29) , - A. S. I. R., Epp. NN. 36, 256 v, ap. S. Leite, II, 437-438.

(30). - C. Jes., III, 38 .

(31). Nota à Hist. Geral, 3a. ed. I, 342 .

(32). - Loc. cit., 48.

(33). - Ibidem, 40 . 
fazer e se enviem ao mesmo tempo, alguns dos Irmãos àquelas nações, contanto que sobejem" (34).

Por sua vez, escrevia da Bahia, a 27 de dezembro de 1554 (35) para Santo Inácio o Padre Luís da Grã: "Eu estou de caminho (para São Vicente), que me manda o Provincial ir; e que deixasse aqui o Pe. Ambrósio Pires, que está em Pôrto Seguro, para que tenha cargo desta casa. Escreveu-me que sưa determinação era não nos dividirmos por tantos lugares, mas ter esta casa por ser cabeça, e a de São Vicente, porque é a entrada para um gentio em que se espera mais fruto que neste" (36). Só duas casas queria Nóbrega conservar no Brasil. E nelas não se incluira o Colégio de São Paulo!

Fatôres alheios à sua vontade haviam-no compelido aos poucos a adotar a solução de Piratininga. Da capital da colônia, lugar evidentemente mais indicado para o estabelecimento do Colégio da Companhia - como logo mais lembrará El-Rei (37) o afugentara a estranha atitude do Bispo. As excelentes disposições de Tibiriçá, de Caiubí, de Tamandiba "grande principal de Piratininga", de que fala Anchieta (38), e que poderia ter sido o terceiro morubixaba, desconhecido, a abraçar o cristianismo; a vantagem de manter os corumins de São Vicente junto aos pais, no planalto; a chegada de Anchieta, permitindo que a nova casa se fundasse sob a forma de um Colégio da Companhia; e, sobretudo, o veto do Governador Tomé de Sousa e depois Duarte da Costa, impedindo a internação domiciliar no continente, eis os caminhos da Providência para a fundação de São Paulo.

Nóbrega, porém, voluntarioso como era, não desistia do plano primitivo. Faltou-lhe vasa para executá-1o. A proibição do Governador se reforçava, dentro em pouco, com a vontade do Rei (39); nà deliberação, ou consulta de 1555 , após a chegada de seu colateral a São Vicente, o parecer de Grã foi inteiramente contrário (40) : a tentativa de penetração executada por Pero Correia e João de Sousa, coroou-se pelo glorioso martírio dos dois jesuítas, pelo Natal de 1554. Era ainda a misteriosa Providência, salvaguardando, contra as intenções de Nóbrega, a existência da cidade nascente.

E foi conhecendo tudo isso que os antigos jesuítas, sem omitir o papel de Nóbrega, deixaram sem dúvida de o realçar - como atualmente se tem feito, com evidente exagêro! -, na fundação de São Paulo. Fundador é êle, se bem que praeter intentionem... Acomodou-se à fôrça das circunstâncias. Velou, depois, sôbre a nova fundação. A êle, sobretudo, se deve a junção de Santo André,

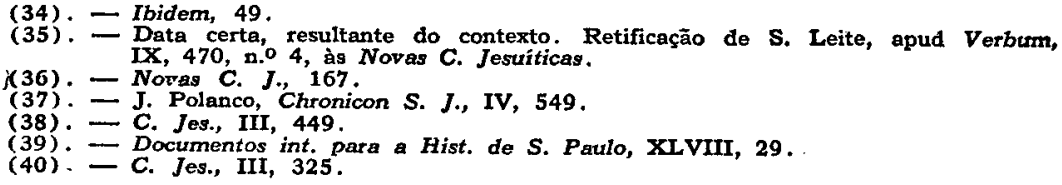
IX, 470, n.o 4, às Novas C. Jesuíticas 
em 1560, acontecimento com que assegurou a sobrevivência de São Paulo, onde o Colégio era a única coisa - confessa Nóbrega, em setembro de 1557, escrevendo a Miguel de Torres, que poderia fazer "que os moradores não despovoem aquela Capitania" (41).

Enquanto isso não se deu, êsse Colégio - "a melhor coisa que há nesta Capitania", dirá a representação da Câmara a Estácio de Sá, em 1564 - e no Colégio, com êle identificado, Anchieta é quem, na prática, sustenta a posição. "O Padre Nóbrega, quando daqui foi - escreve de Piratininga Luís da Grã a Santo Inácio, a 7 de abril de 1557 - deixou esta Aldeia... povoada de índios, dos quais muitos já eram cristãos e catecúmenos. Mas êles são tão costumados a mudarem-se, quando as suas casas são velhas, que cada três ou quatro anos... se mudam; e, que é pior, não vão juntos".. "Assim foi nesta Aldeia, que só uma casa ficou, em que haverá cinco ou seis homens casados: mudar-se-ão quando a casa cair"... (42).

Com a debandada dos piratininganos em 1556, extinguiu-se o que oficialmente se iniciou na "nova aldeia" de Piratininga a 29 de agôsto de 1553: a "cidade nobreguense". Sobreviveu, com o Colégio fundado a 25 de janeiro de 1554, São Paulo de Anchieta, a única que os paulistas até hoje conhecem.

PE. HELIO ABRANCHES VIOTTI, S. J. 